Article (refereed) - postprint

Welch, D.. 2016. The floristic changes of Scottish moorland dominated by heather (Calluna vulgaris, Ericaceae) but unburnt for 50 years and kept checked by moderate grazing.

(C) 2016 Botanical Society of Britain \& Ireland

This version available http://nora.nerc.ac.uk/515261/

NERC has developed NORA to enable users to access research outputs wholly or partially funded by NERC. Copyright and other rights for material on this site are retained by the rights owners. Users should read the terms and conditions of use of this material at

http://nora.nerc.ac.uk/policies.html\#access

This is an Accepted Manuscript of an article published by Taylor \& Francis Group in Bird Study on 21/06/2016, available online: http://www.tandfonline.com/doi/full/10.1080/20423489.2016.1178061 


\section{David Welch}

Centre for Ecology \& Hydrology, Edinburgh Research Station, Bush Estate, Penicuik, Midlothian, EH26 0QB, UK.

Vegetation and herbivore usage have been monitored since 1969/1970 at four moorland sites where heather (Calluna vulgaris) remained the main species under moderate levels of grazing. Much of the annual growth of the heather was regularly consumed by this grazing, but no burning occurred to remove heather biomass. Two sites were on acidic base-poor soils and had only minor cover of grasses and herbs, their vegetation having most affinity to H10 heath in the National Vegetation Classification of British plant communities. The other two sites were on more base-rich soils, and grasses and herbs had substantial cover; their vegetation showed most affinity to NVC CG11a grassland. One of the latter sites lies at $700 \mathrm{~m}$ and Calluna grew poorly being close to its altitudinal limit; the other three sites were at lower altitude and Calluna grew strongly creating dense swards. Over the 43-44 years of observation Calluna increased moderately in height but many subordinate higher plants declined in cover, as measured by point-quadrat recording. Bryophytes increased at three sites largely due to substantial gains of Hylocomium splendens, but other pleurocarpous mosses suffered some declines. At the three lower-altitude sites species number fell by $20-35 \%$ between the first and last recordings, but at the high-altitude site there was negligible change in species number. The main drivers of change were the grazing received and the performance of Calluna, and no evidence was found of species composition reacting to climate change or nitrogen deposition. To maintain diversity, timely burning is recommended.

Keywords: Floristics, Grazing, Heather moorland, Long-term monitoring, NVC plant communities, Vegetation change

\section{Introduction}

Heathlands with dominant heather (Calluna vulgaris) occur extensively in upland Britain, and nine National Vegetation Classification (NVC) communities of this type, excluding mires, are recognised in Scotland (Rodwell, 1991). These communities are differentiated most importantly by altitude and soil type, but in reality there is a continuum of compositional variation and the communities are simply convenient reference points (Averis et al., 2004). Moreover there are many transitional communities to the different types of grassland that develop when heather moorland is heavily grazed by large herbivores (Welch, 1984a). In Europe heathland is an endangered habitat being listed in the EC Habitats Directive 92/43/EEC (Newton et al., 2009), and the heather moors of upland Britain are important due both to their large extent and high conservation value (Thompson et al., 1995). 
Most heather moorland in Britain is maintained by burning, this management being carried out at approximately 20-year intervals to create suitable habitat for red grouse and nutritious forage for livestock (Hester \& Sydes, 1992; Yallop et al., 2006); unless burnt the moors would often be colonised by trees and eventually develop into woodlands. Burning much affects the botanical composition of heathland, and some experimental studies have recorded post-fire successions e.g. Hobbs \& Gimingham (1984) for NE Scotland and Vandvik et al. (2005) for Norwegian coastal heathland. This latter study also assessed the impact of sheep grazing by having fenced-off control ground for each of three habitat types, but in both these studies composition was observed for only a short time (5-6 years) after burning. Other workers have examined vegetation in known-age burnt patches of moorland, e.g. Harris et al. (2011), without recording the grazing received since the fires. But to fully understand the determinants of heathland composition it is necessary to monitor the period following the initial postfire recovery especially because this phase may last for over forty years, thereby making small one-direction changes become important.

Long-term vegetation changes have been assessed in some Scottish upland sites, notably over 50 years by Ross et al. (2012), but the grazing pressures allowing or causing these changes have not been monitored, and the lack of intermediate observations has meant that persistent steady change cannot be distinguished from short-term variation. Moreover short-term fluctuations immediately prior to final observations may lead to misleading assessments of long-term trends. The inadequacy of knowledge on post-fire moorland successions in Britain is now widely recognised, e.g. by Harris et al. (2011) who comment that the lack of reliable predictive information to inform conservation has resulted in controversy about best management policies.

The state of approximate heather balance (annual growth increment being balanced by the combined losses from die-back and herbivore offtake, so that cover stays unchanged) is currently quite rare in Scotland, since besides the widespread regularly-burnt moorlands there are many moorlands that have recently been so heavily grazed as to become grasslands (Thompson et al., 1995). However burning management of heathland is often less intensive in Scotland than England (Hester \& Sydes, 1992; Yallop et al., 2006), the former study finding that only c. $2 \%$ of heather moorland was burnt each year up to 1988; more recently the extent of long-unburnt heathland has probably increased in Scotland due to a decline in the profitability of 
1 grouse shooting and shortages of manpower to carry out the necessary burning. Also red deer doubled in number from the 1960s to the late 1980s in Scotland (CluttonBrock, 1999), so more of the annual growth of heather is being consumed in many upland areas and hence there is less need for burning to keep heather short. Heatherin-balance sites used to be valued as grazing for livestock and were probably more extensive in past centuries, as shown by 1807-09 estate maps for west Aberdeenshire (RHP 3897, National Archives of Scotland) having annotations such as "short heath, pretty good grazing".

A study monitoring continually both vegetation composition and grazing began on heather moorland in north-east Scotland in 1969/1970, and provides some definite

11 information on long-term moorland compositional change. Some 32 sites being grazed 12 by cattle, sheep and red deer were established on a range of soil types at a range of 13 altitudes (Welch, 1984b); at 15 sites the monitoring lasted for 20 years at which time 14 the findings were reported in Welch \& Scott (1995). Herbivore usage was found to 15 have been the main driver controlling trends in heather cover: at four sites with heavy grazing heather declined sharply, at four sites with moderate grazing its cover changed little, and at the other seven sites with lighter grazing the cover of heather increased. Monitoring continues at most of the sites, but now a further assessment of the nature and rate of long-term compositional change is being made for each of the three different grazing-intensity states. Change from heathland to grassland at three sites with dry soils was reported in Welch (2013) and the present paper reports observations over 4344 years at four sites not burned in that period but at which moderate grazing from large herbivores kept heather cover and height checked.

Major disturbances to heathland like burning and heavy grazing have been found to cause short-term increases in species richness (Harris et al., 2011; Hancock \& Legg, 2012), so to counterbalance these increases a decline in species richness in littledisturbed heathland could be expected during the period following post-fire recovery, otherwise each burning cycle would produce a rise in biodiversity. So for the four sites now reported the hypotheses to be tested are first that species number declines over several decades when only moderate grazing occurs, and second that the flux in species occurrence leads to the vegetation at the sites changing in its NVC affinity.

33 Study sites 
1 The sites chosen for monitoring when the original study began in 1969/1970 were all

2 being grazed and with vegetation not in the initial phase of recovery after burning. This was ascertained from aerial photographs taken in the early 1960s and from consultation with local farmers, gamekeepers and owners. All four of the sites now reported are situated in the eastern Grampians, with altitudes ranging between $107 \mathrm{~m}$ and $701 \mathrm{~m}$ (Table 1 - site codes are retained from Welch (1984b)). The sites lie 25 to $70 \mathrm{~km}$ from the coast (Fig. 1), so have a hemi-oceanic climate; for the closest meteorological stations, Aboyne (207 m altitude) and Braemar (340 m altitude), respectively $10 \mathrm{~km}$ distant to site D2 and 6-13 km distant to sites L1, L2 and O2, averages for the 19812010 period were: January mean temperature 2.5 and 1.5 deg. C, July mean temperature 14.4 and $13.1 \mathrm{deg}$. C, annual days air frost 86 and 102, and annual rainfall 780 and 932 $\mathrm{mm}$.

The soils of all four sites are derived from drift, and at the start of the study ranged in $\mathrm{pH}$ from 3.8 to 5.3 (Table 1). Site D2 was well drained with a podsol soil, L2 was wetter with a peaty gley soil, and sites L1 and $\mathrm{O} 2 \mathrm{had}$ brown earths richer in cations. Initially Calluna was dominant at sites D2, L1 and L2 as a carpet with low height, but at the highest-altitude site, O2, Calluna occurred only in low patches, with grasses prominent both within and between the patches.

Grazing management and type differed between sites (Table 1). At site D2 there was a large tract of heather moorland over which the sheep flock could graze at will, but the monitored ground was quite near a gate through which livestock were brought onto the moorland from improved pasture, and sometimes the gate was left open allowing the pasture and moorland to be grazed in tandem. The other three sites were in a block of uplands some 200 square kilometres in area that had no improved grassland. Sheep flocks were grazed there from May to October each year, and red deer were present year-round; they mostly utilised sites L1 and L2 during the winter months November to April and moved up to higher ground in summer. Site O2 attracted considerable use from sheep despite its high altitude, and usage by red deer was only sporadic although year-round.

Definite dates for when the four sites were last burnt are not available. However the upland containing sites L1, L2 and O2 was being managed primarily as a grouse moor in the 1950s and 1960s, with all lower ground being periodically burnt. Hence L1 and L2 are likely to have been burnt in the period 15 to 30 years before the observations began; the 1960s aerial photographs merely indicate that any burning was 
not recent either at them or site $\mathrm{O} 2$. At site $\mathrm{D} 2$ the moorland had long been primarily managed for a winter grazing for sheep, its owner believing in 1970 that it had not been burnt for over 50 years and many old heather bushes were present then despite the low sward height (Welch \& Kemp, 1973).

\section{Methods}

The four sites were set up within tracts of relatively homogenous vegetation, and were 0.5-1.0 ha in extent. Within each site eight $15 \mathrm{~m} \mathrm{x} 1 \mathrm{~m}$ permanent monitoring plots were laid out; measurements on herbivore occupancy were made within the plots and measurements on vegetation alongside the plots. Monitoring began at L1, L2 and O2 in summer 1969 and at D2 in summer 1970. For this paper the final recordings were obtained in 2013 and 2014, although monitoring continues.

Occupancy of cattle, sheep, red deer, hares + rabbits, and red grouse was assessed separately, by collecting all dung newly deposited on the plots at 3-week intervals and measuring its volume from the water displaced in a cylinder. This was done for the first seven years of the study; thereafter volume equivalents were estimated from the standing crop of dung present in April and September each year using a sixpoint index scale: e.g. scale points 3 and 5 for sheep were assigned for 12 to 30 and 60 to 180 pellet groups respectively lying in the eight plots, and were deemed to contribute 14.5 and $83 \mathrm{ml} \mathrm{m}^{2}$ of dung respectively. To produce the yearly totals of herbivore occupancy (Fig. 2), totals for the five types were added, the volume for cattle being first divided by 1.8 to allow for its low dry-matter content (Welch, 1982).

Calluna shoot utilisation and height were recorded at 16 permanent positions, in two $1-\mathrm{m}^{2}$ squares per plot. For utilisation the percentage of the main shoots present that had been browsed was assessed in each $1-\mathrm{m}^{2}$ position on a 4-point index scale and then averaged from the 16 assessments; recording was done each September and also each April, giving a maximum estimate at the end of winter before new growth started. Height was recorded each September by 10 spot measures at each permanent position, a mean being obtained from the 160 measures. The annual means for Calluna utilisation and height during the whole study period are shown in Fig. 2.

Plant cover was estimated by point-quadrat recording mostly at two or threeyear intervals. A 10-pin frame $1 \mathrm{~m}$ long was placed in 10 positions alternately parallel and normal to the long axes of the monitoring plots and $1 \mathrm{~m}$ apart, giving 800 points per site. The pins were held vertically, and for each pin every species contacted was 
recorded. Recordings were made between late June and the start of August, the timing at each site being kept within a few days of its initial date.

For a basic assessment of change in vegetation composition (Fig. 3), the species were grouped according to type: bryophytes, lichens, ericoids (Calluna, Erica, Vaccinium), unpalatable graminoids (Juncus, Molinia, Nardus, Trichophorum) and graminoids-herbs (all other angiosperms). A group was recorded for a pin if any member species was hit. To examine the behaviour of individual main species, those with cover exceeding $10 \%$ in at least one recording, the first step was regression against time of their cover in all recordings, so species for which time explained a significant part of cover change were recognised. Then for these reactive species, the directions of change in all 8 plots at each site were compared to the overall site change. Next for all main species, counts were made of cover gains and losses for all intervals between successive analyses, so the incidence of short-term direction reversals against overall change could be calculated. To display the overall behaviour of these main species, cover averages were calculated for two successive recordings at the start, middle and end of observations, and are presented in Table 3, which also reports regression significances and the incidences of reversal in change direction. New species and species apparently lost from the sites were identified (Tables 4 and 5), and changes in species richness are presented in Figs. $4 a$ and $4 b$, respectively of the total number of species encountered in 800 points and the mean number of species hit at a single point. Classification (Rodwell et al., 1992) was assessed using TABLEFIT (Hill, 1996). This was done both for the composition of the sites in year 1 of the observations and for their final composition in year 43/44. When all species were used in the assessments there was a long tail of species that had negligible cover and were only intermittently recorded, which tended to make the vegetation fit more species-rich NVC types. So further assessments were made including only species with mean cover greater than $1 \%$ in the diagnoses.

Nomenclature follows Stace (2010) for vascular plants, Smith (2006) for mosses, Paton (1999) for liverworts, and Purvis et al. (1992) for lichens. However Hypnum cupressiforme possibly includes other segregate species from the complex so named by Smith (1978).

\section{Results}


1 Vegetation composition

2 Vegetation composition reflected the differences in soil type, sites D2 and L2 being

3 poor in species, whereas sites $\mathrm{L} 1$ and $\mathrm{O} 2$ were quite rich in species especially

4 dicotyledonous ones (Table 2). Grasses particularly Agrostis capillaris and Festuca

5 ovina had greater cover at the latter two sites. The main mosses also differed between

6 sites, with Pleurozium schreberi prominent at the two base-poor sites and Hylocomium

7 splendens prominent at $\mathrm{L} 1$ and $\mathrm{O} 2$. For all four sites, the mean number of dicots and

8 lichen species present in individual recordings was low compared to the total observed

9 in all recordings (Table 2), many of these species having mean cover less than $1 \%$ and

10 only being recorded intermittently.

12 The grazing received and its impact

13 Herbivore occupancy was greater in most years at sites L1 and L2 than sites D2 and O2

14 (Fig. 2). At L1 and L2 some variability resulted from the extent to which deep snow on 15 nearby higher ground brought down red deer to graze the sites in winter. At site D2 16 sheep were the only large herbivore until 2002, when cattle grazing began after the 17 farm lease changed. The sharp reduction in occupancy here from 1988/89 onwards was 18 associated with a run of mild winters during which the sheep could utilise grasslands 19 elsewhere on the farm; it was paralleled at D2 by a fall in Calluna utilisation and a 20 steady rise in Calluna height (Fig. 2). At the other three sites Calluna height rose more 21 gradually and by less in total amount, by $5 \mathrm{~cm}$ at site $\mathrm{O} 2,7 \mathrm{~cm}$ at $\mathrm{L} 1$ and $11 \mathrm{~cm}$ at L2

22 (Table 1); for 44-year periods these height increments are minor compared to the $25-\mathrm{cm}$ rises expected over 20 years on many moorlands managed on burning rotations for grouse shooting.

At site $\mathrm{O} 2$ the combined occupancy from red deer, sheep and mountain hares was less than half as great as at the nearby L1 and L2 sites, which probably resulted from its more exposed situation and higher altitude (Table 1). But Calluna percentage utilisation was little different from that at L1 and L2, reflecting the year-round presence of mountain hares and their year-round preference for grazing on Calluna. In contrast,

31 Calluna since they prefer to graze grasses and herbs at this time of year. The small

32 increase in Calluna height at $\mathrm{O} 2$ during the study also resulted from its smaller annual

33 increment there (Table 1), and the browning or die-back of the bushes observed in some 34 years after severe winters. 
2 Changes in vegetation composition

3 The ericoid species group, with Calluna its main species, stayed dominant at the base-

4 poor sites D2 and L2 throughout the study and showed only minor variations in cover

5 (Fig. 3). The graminoids-herbs group had initially only half the cover of ericoids at

6 these sites and lost cover erratically during the study, its final contribution being $26 \%$ at

7 D2 and just $16 \%$ at L2. At both these base-poor sites bryophytes were abundant and

8 increased, so latterly they formed a nearly continuous carpet below the Calluna canopy.

9 At sites L1 and $\mathrm{O} 2$ with richer soils graminoids-herbs initially had more total cover

10 than ericoids, but gradually lost cover; at L1 this probably resulted from the increase in

11 Calluna height to $21 \mathrm{~cm}$ in 2013 (Table 1). Unpalatable graminoids had substantial

12 cover only at site L2, and declined sharply there, their main species (Juncus squarrosus

13 and Nardus stricta) being constrained by the increasing height of Calluna. Lichens

14 were rare at L1, L2 and O2, never exceeding 2\% cover, and are only shown in Fig. 3 for

15 site D2. Here they tolerated the sheep grazing and maintained substantial cover until

16 cattle began to use the site in 2002 ; they then suffered trampling damage and were

17 reduced to $4 \%$ cover by 2010 .

18 Calluna and some other major individual species changed little in cover during

19 the study, but significant declines were experienced by 22 of the 46 main species that

20 had cover $>10 \%$ in at least one recording (Table 3 ). On single plots the direction of

21 species change differed very rarely from the overall direction occurring at their site

22 (incidence of 3\%), hence only site means are used here. The significantly-declining

23 species had on average final cover just one third of their initial cover, and only two of

24 them, Agrostis capillaris and Festuca ovina at site L1, retained more than $60 \%$ of their

25 initial cover. Despite many declines being highly significant over $43 / 44$ years, none

26 occurred consistently between every successive recording without a reversal; the

27 species most consistently declining, Hypnum cupressiforme at L1, had 3 reversals in 14

28 intervals hence $21 \%$ reversal in Table 3 . The stable species shown in bold in the table

29 had almost as many direction reversals as direction holds, as could be expected,

30 averaging $46 \%$ reversal of direction compared to $36 \%$ reversal of direction for species

31 changing significantly. Two cover increases, those of the hypnoid moss Hylocomium

32 splendens at the base-poor sites, were very great since its initial cover was negligible.

33 Hylocomium also increased markedly at the base-rich sites, partially replacing Hypnum

34 cupressiforme and Pleurozium schreberi in the moss carpet there. The only higher 
1 plant showing a large gain in cover was Deschampsia flexuosa at site D2, where it

2 appeared to be replacing Festuca ovina in a niche utilising small gaps in the dense

3 heather sward.

New species were very few, mostly at site O2, and had attained very little cover by the final observations (Table 4); at $\mathrm{O} 2$ they may well have been present sparsely before the study began but not touched in the first two recordings. Lost species were more numerous especially at site D2 (Table 5). The ones last recorded early in the study or with average cover greater than $1 \%$, are very likely to have become locally extinct, but of the 23 species in Table 5 just three bryophytes and two lichens fall into this group, four of them at site D2.

Total species number (Fig. 4a) and mean number of species hit per point (Fig. 4b) both fell slowly and rather erratically at sites D2, L1 and L2, with the sharpest fall in species number at D2 and in species hit per point at L1. As a result, the vegetation is now notably species-poor at these three sites. But at $\mathrm{O} 2$ species number has remained high, being 66 and 64 in the first and last recordings respectively. This doubtless reflected the low cover and height of Calluna here and consequent lack of competition and shading, much of the fall in species hit per point occurring in the $40 \%$ of points that lay within the Calluna patches. For sites D2, L1 and L2 there was a significant difference $(P<0.05)$ in $t$ tests between species number in the first three and last three analyses, the declines in species number ranging from 22 to $36 \%$.

\section{Affinities of the moorlands}

The top goodness-of-fit values obtained for both initial and final compositions of the four sites mostly rated good (70-79\%) or very good (80\% plus) in TABLEFIT (Table 6). Including all species in the analyses gave somewhat poorer fit than when species with less than $1 \%$ cover were omitted. Initially only site D2 had its closest affinity to a heathland type (Calluna vulgaris-Erica cinerea heath, NVC H10) rather than a grassland type. But due to the decline and loss of graminoids and herbs over the 43/44 years of the study (Tables 3 and 5) site L2 also came to have best allegiance to NVC H10. The presence of Leucobryum glaucum at D2 and Plagiothecium undulatum, Rhytidiadelphus loreus and Sphagnum spp. at L2 probably explains their affinities to the rather moister NVC H18 (Vaccinium myrtillus-Deschampsia flexuosa heath) and H21 (Calluna vulgaris-Vaccinium myrtillus-Sphagnum capillifolium heath) types. 
At the two base-rich sites, L1 and O2, there was initially best fit to NVC

2 CG11a (Festuca ovina-Agrostis capillaris-Alchmilla alpina grass heath), the abundance

3 of Alchemilla alpina, initially with cover $8 \%$ at $\mathrm{L} 1$ and $17 \%$ at $\mathrm{O} 2$, explaining the poorer fit then to NVC CG10a (Festuca ovina-Agrostis capillaris-Thymus praecox grassland). At $\mathrm{O} 2$ species number remained high (Fig. 4a) and the best-fit community remained CG1 1a. Species present at O2, and found by Rodwell et al. (1992) to occur in CG11 but not in CG10, included Anemone nemorosa, Carex bigelowii, Coeloglossum viride, Polytrichum alpinum and Viola palustris. For L1 the reduction in cover of Alchemilla alpina to only $0.4 \%$ in 2012 , thereby causing its omission in the TABLEFIT assessments that had species with $<1 \%$ cover excluded, contributed to the

11 best fits for that class changing to NVC U4a (Festuca ovina-Agrostis capillaris-Galium 12 saxatile grassland, typical sub-community).

\section{Discussion}

15 The major findings of the study were the decline in cover of many graminoid and herb species at the three sites where Calluna remained dominant for over 40 years (Fig. 3, Table 3), the fall in species richness at these sites (Fig. 4a) and the frequent occurrence of short-term reversals to the overall direction of changes in cover and species richness (Table 3, Fig. 4a). The slowness of the changes and their short-term fluctuation make it clear that long-term consistent measurements are needed to assess heathland composition change after the initial phase of post-fire recovery.

Fluctuations in cover arise from many causes such as damage from snow-lie, disease, drought, frost incidence, growing conditions in the weeks before the analyses with bryophytes for example attaining more cover in wet than dry years, and the resulting variability can easily obscure any slow changes over short periods. For species richness there is also an intrinsic problem caused by the long "tails" of species having little cover in many plant communities; at the study sites a quarter to a third of all the species present had $<1 \%$ cover, increasing the chance of the point quadrats missing them. But given that the present monitoring continued for over 40 years, it seems very likely that the two conclusions on graminoid and herb decline and on species impoverishment are a reality in sites with a constant high Calluna cover.

The decline in species richness was greatest at site D2 and correlated with an increase in Calluna height. This site had long been grazed quite heavily by sheep,

34 keeping sward height down to c. $8 \mathrm{~cm}$ (Fig. 2). But a decrease in grazing occupancy in 
1 the late 1980s let Calluna height increase to $15 \mathrm{~cm}$ and coincided with a fall in the cover of graminoids-herbs (Fig. 3). Species lost, never recorded after 1990, included several bryophytes and lichens (Table 5) and also Dactylorhiza maculata, Gymnadenia conopsea, Polygala serpyllifolia and Poa pratensis too rare in the first twenty years of monitoring to appear in Table 5. Although bryophytes as a group gained cover at D2 (Fig. 3) due to a spread of pleurocarpous mosses especially Hylocomium splendens (Table 3), the number of bryophyte species declined. Total species number averaged 38 for the first three recordings but then fell as Calluna height rose (Fig. 4a). That diversity had remained moderately high despite perhaps 50 years having elapsed without burning, is an important result that shows it is the combination of Calluna dominance and height that impacts on graminoids and herbs.

Sites L1 and L2 also remained Calluna-dominant (Fig. 3, Table 3), the greatest change being the decline in unpalatable graminoids especially Nardus stricta at L2.

4 The impact of taller Calluna swards on Juncus squarrosus and Nardus at the original

(1)
study sites was reported in Welch (1986), where for Nardus substantial declines occurred when the product of Calluna height (cm) and cover \% exceeded 1000, e.g. 18 x $55 \%$ or $20 \times 50 \%$; the trends at L2 since 1983 were consistent with these earlier findings. Other big changes in cover at L1 and L2 came from interplay between bryophytes, notably Hypnum cupressiforme being ousted by Hylocomium splendens in the moss carpets. At site L1 five graminoid and herb species showed large declines (Table 3), explaining the sharp fall in species hit per point there (Fig. 4b). These species were not lost from the site and hence species number declined only modestly (Fig. 4a).

Site $\mathrm{O} 2$ stayed rich in species throughout the study (Fig. 4) and its close affinity to NVC Festuca ovina-Agrostis capillaris-Alchemilla alpina grassland remained unchanged (Table 6). Evidently the cover and height of Calluna, ranging from 29 to $41 \%$ and 9 to $17 \mathrm{~cm}$ respectively over the 44 -year period (Tables $1 \& 3$, Fig. 2), was insufficient to cause more than a minor decline in graminoids-herbs cover (Fig. 3) and only three bryophytes that had tiny cover were classed as lost during the study (Table 5). That species number stayed high at $\mathrm{O} 2$ gives a control that implies the declines in species number at the other sites were real and not caused by method changes or recorder failure to observe species.

For all four sites just five species were new, entering after observations began (Table 4). In contrast there were 23 new species observed by identical recording 
1 methods over a similar period at three sites where Calluna stands became grasslands

2 (Welch, 2013). Moreover at the present sites with Calluna checked but still dominant

3 the number of species lost far exceeded new species, with 20 altogether for D2, L1 and

4 L2 (Table 5), and another 16 angiosperm species were probably lost but not given in

5 Table 5 having less than four occurrences; these included Achillea ptarmica, Alchemilla

6 filicaulis and Succisa pratensis besides the two orchids already mentioned for D2. This

7 indicates that conditions in taller dense Calluna swards are hostile for many

8 angiosperms that are otherwise adapted to the local climate and soil conditions. It can

9 be concluded that at sites with Calluna dominant and over $15 \mathrm{~cm}$ tall, species richness

10 will slowly decline to a very low level unless some major event damages the heather,

11 e.g. attack by heather beetles (Lochmaea suturalis), fire, or heavy grazing.

12 Similar species poverty was reported for the moorland community called

13 Callunetum vulgaris by McVean \& Ratcliffe (1962), now considered a main component 14 of NVC H10 heath (Rodwell et al., 1991). In 4-m² quadrats the mean number of 15 species was just 17 for Callunetum vulgaris, lower than for any other of the moorland 16 and grassland communities described by McVean \& Ratcliffe in the Scottish Highlands.

17 Very low numbers of species were found in related Calluna moorland (Hobbs \& 18 Gimingham, 1984; Harris et al., 2011), though the communities in the Peak District 19 studied in the latter paper were rather moister than the present four sites. In both these 20 studies declines of graminoid and herb species were observed after burning, being 21 inversely related to vegetation height (Harris et al., 2011). However no study on 22 heathland botanical composition has yet reported changes through an entire post-fire succession. Also change in NVC affinity such as occurred at site L2 has not previously been demonstrated for moderately grazed, unburnt moorland in Britain. Species of conservation concern in Britain occurred at sites D2, L2 and O2. Cheffings \& Farrell (2005) class Coeloglossum viride (O2) as "Vulnerable", the thirdhighest threat category in the IUCN Scheme, and Genista anglica (D2 and L2) is "Near Threatened", the fourth-highest category. Also Potentilla crantzii (O2) is classed as "Nationally Scarce". British NVC plant communities have not been categorised on rarity or threat of decline, but two of the present sites do have conservation value in their communities being relatively scarce. NVC U4a and NVC CG11a grasslands have quite limited distribution (Rodwell et al., 1992) and our particular communities at L1 and $\mathrm{O} 2$ with abundant Calluna are not given a separate status in NVC that they

34 probably merit. Opinion is divided on how best to conserve heathlands (Newton et al., 
1 2009), with managers e.g. English Nature often believing that burning has resulted in moorland being in "unfavourable" condition (Stewart et al. (2005), but researchers e.g. Bartoleme et al. (2005) report that burning is more effective than grazing alone at maintaining diversity. The present study does show that grazing alone is insufficient to maintain species richness in many lower-altitude situations, giving support to the conclusions of Harris et al. (2011) that in them prescribed burning should be regularly employed. However, heavy grazing that caused a major decline of Calluna at another site in NE Scotland did result in species diversity rising (Welch, 2013).

The present long-term observations have provided no evidence that thermophilous plants with a Southern distribution in Britain are moving north or to

11 higher altitudes, although the closed nature of the swards and lack of bare ground 12 clearly reduce the chances of colonisation. Also the observed trends do not give 13 support to either explanation suggested by Maskell et al. (2010) for the association of 14 declines in species richness with increased nitrogen deposition, that 1) enhanced growth of dominants suppresses subordinate species, or 2) acidification or direct $\mathrm{N}$ toxicity damages some species. Relevant to 1), the annual growth increment of Calluna fell at three of the present sites after 1990 compared to its initial average; the exception was high-altitude site $\mathrm{O} 2$, for which the most likely explanation was higher summer temperature in recent years than before 1990. Relevant to 2), Maskell et al. showed a correlation between increased $\mathrm{N}$ deposition and lower cover of several herbs and mosses including Hylocomium splendens, but that moss increased very sharply at all the present sites. With intermediate levels of nitrogen deposition in upper Deeside (14-20 $\mathrm{kg} \mathrm{ha}^{-1}$ recently estimated for nearby Glas Maol (Pearce et al., 2003; Armitage et al., 2011), and $\mathrm{N}$ deposition rates having remained fairly constant over the past forty years, the clear gains of Hylocomium splendens at the expense of Hypnum cupressiforme seem not to be caused by $\mathrm{N}$ deposition.

\section{Conclusion}

29 The main factors affecting the floristics of heathland once the initial recovery after burning has occurred, are the grazing received and the sward height and dominance of

31 Calluna. The hypothesis that species diversity declines in the long term during the succession stage after initial post-fire recovery under moderate grazing was shown correct, but qualified by this occurring only when Calluna swards reach heights of 15 
1 during a prolonged post-fire stage can be sufficiently great as to change NVC affinity was shown true at two of the four sites, due to declines in number and cover of herbs and graminoids. To maintain floral diversity in heathlands there needs to be regular burning, so that the succession stage when Calluna sward heights exceed $20 \mathrm{~cm}$ is minimised.

\section{Acknowledgements}

8 I am grateful to the estate owners and their farmers for permission to visit the sites and

9 frequent conversations over the years. Many staff of the former Banchory Research

10 Station of the Institute of Terrestrial Ecology assisted with the fieldwork early in the

11 study, then David Scott and more recently my wife, Muriel Welch, have patiently

12 recorded my point-quadrat observations. Dr Ruth Mitchell of the James Hutton

13 Institute, Aberdeen, and Dr Colin Legg, Edinburgh University School of Geo Sciences, 14 commented on earlier versions of this paper, and Dr Micheline Sheehy Skeffington and 15 two anonymous referees have made valuable improvements.

\section{References}

Armitage, H. F., Britton, A. J., Woodin, S. J. \& van der Wal, R. 2011. Assessing the recovery potential of alpine moss-heath: reciprocal tranplants along a nitrogen deposition gradient. Environmental Pollution, 159: 140-147.

Averis, A. M., Averis, A. B. G., Birks, H. J. B., Horsfield, D., Thompson, D. B. A. \& Yeo, M. J. M. 2004. An illustrated guide to British upland vegetation. Peterborough: JNCC.

Bartolome, J., Plaixats, J., Fanlo, R \& Boada, M. 2005. Conservation of isolated Atlantic heathlands in the Mediterranean region: effects of land-use changes in the Montseny biosphere reserve (Spain). Biological Conservation 122: 81-88.

\section{Cheffings, C. \& Farrell, L. (eds.) 2005. The Vascular Plant Red Data List for Great} Britain. Peterborough: JNCC.

Clutton-Brock, T. H. 1999. Variation in red-deer density in the Highlands. Information \& Advisory Note No. 100, Scottish Natural Heritage, Inverness.

Hancock, M. H. \& Legg, C. J. 2012. Diversity and stability of ericaceous shrub cover during two disturbance experiments; one on heathland and one in forest. Plant Ecology \& Diversity 5: 275-287. 
Harris, M. P. K., Allen, K. A., McAllister, H. A., Eyre, G., Le Duc, M. G. \& Marrs, R. H. 2011. Factors affecting moorland plant communities and component species in relation to prescribed burning. Journal of applied Ecology 48: 1411-1421.

Hester, A. J. \& Sydes, C. 1992. Changes in the burning of Scottish heather moorland since the 1940s from aerial photographs. Biological Conservation 60: 25-30.

Hill, M. O. 1996. TABLEFIT V1.0, for identification of vegetation types. Huntingdon: Institute Terrestrial Ecology.

Hobbs, R. J. \& Gimingham, C. H. 1984. Studies on fire in Scottish heathland communities. II. Post-fire vegetation development. Journal of Ecology 72: 585-610.

Maskell, L. C., Smart, S. M., Bullock, J. M., Thompson, K. \& Stevens, C. J. 2010. Nitrogen deposition causes widespread loss of species richness in British habitats. Global Change Biology 16: 671-679.

McVean, D. N. \& Ratcliffe, D. A. 1962. Plant Communities of the Scottish Highlands. Monographs of the Nature Conservancy No 1. London, H. M. S. O.

Newton, A. C., Stewart, G. B., Myers, G., Diaz, A., Lake, S., Bullock, J. M. \& Pullin, A. S. 2009. Impacts of grazing on lowland heathland in north-west Europe. Biological Conservation 142: 935-947.

Paton, J. A. 1999. The liverwort flora of the British Isles. Colchester: Harley Books.

Pearce, I. S. K., Woodin, S. J. \& van der Wal, R. 2003. Physiological and growth responses of the montane bryophyte Racomitrium lanuginosum to atmospheric nitrogen deposition. New Phytologist 160: 145-155.

Purvis, O. W., Coppins, B. J., Hawksworth, D. L., James, P. W. \& Moore, D. M. 1992. The lichen flora of Great Britain and Ireland. London: The British Museum (Natural History).

Rodwell, J. S., ed. 1991. British Plant Communities. 2. Mires and heaths. Cambridge: Cambridge University Press.

Rodwell, J. S., ed. 1992. British Plant Communities. 3. Grassland and montane communities. Cambridge: Cambridge University Press.

Ross, L. C., Woodin, S. J., Hester, A. J., Thompson, D. B. \& Birks, H. J. 2012. Biotic homogenization of upland vegetation patterns and drivers at multiple spatial scales over five decades. Journal of Vegetation Science 23: 755-770.

Smith, A. J. E. 1978. The Moss Flora of Britain and Ireland. Cambridge: Cambridge University Press.

Smith, A. J. E. 2006. The Moss Flora of Britain and Ireland. Cambridge: Cambridge University Press. 
Stace, C. A. 2010. New Flora of the British Isles. $3^{\text {rd }}$ edition. Cambridge: Cambridge

2 University Press.

Stewart, G. B., Coles, C. F. \& Pullin, A. S. 2005. Applying evidence-based practice in conservation management: lessons from the first systematic review and dissemination projects. Biological Conservation 126: 270-278.

Thompson, D. B. A., MacDonald, A. J., Marsden, J. H. \& Galbraith, C. A. 1995. Upland heather moorland in Great Britain: a review of international importance, vegetation change and some objectives for nature conservation. Biological Conservation 71: 163-178.

Vandvik, V., Heegaard, E., Maren, I. E. \& Aarrestad, P. A. 2005. Managing heterogeneity: the importance of grazing and environmental variation on post-fire succession in heathlands. Journal of applied Ecology 42: 139-149.

Welch, D. 1982. Dung properties and defecation characteristics in some Scottish herbivores, with an evaluation of the dung-volume method of assessing occupance. Acta Theriologica 27: 191-212.

Welch, D. 1984a. Studies in the grazing of heather moorland in north-east Scotland. III. Floristics. Journal of applied Ecology 21: 209-225.

Welch, D. 1984b. Studies in the grazing of heather moorland in north-east Scotland. I. Site descriptions and patterns of utilisation. Journal of applied Ecology 21: 179-195.

Welch, D. 1986. Studies in the grazing of heather moorland in north-east Scotland. V. Trends in Nardus stricta and other unpalatable graminoids Journal of applied Ecology 23: $1047-1058$.

Welch, D. 2013. The floristics of contrasting grazed-down Scottish moorland sites initially dominated by heather (Calluna vulgaris). New Journal of Botany 3: 169-177.

Welch, D. \& Kemp, E. 1973. A Callunetum subject to intensive grazing by mountain hares. Transactions of the Botanical Society of Edinburgh 42: 89-99.

Welch, D. \& Scott, D. 1995. Studies in the grazing of heather moorland in north-east Scotland. VI. 20-year trends in botanical composition. Journal of applied Ecology 32: 596-611.

Yallop, A. R., Thacker, J. I., Thomas, G., Stephens, M., Clutterbuck, B., Brewer, T. \& Sannier, C. A. D. 2006. The extent and intensity of management burning in the English uplands. Journal of applied Ecology 43: 1138-1148. 


\section{Figure Captions}

Fig. 1 Location of the four study sites and two meteorological stations (+, A = Aboyne, $\mathrm{B}=$ Braemar) within inset from a map of Scotland.

Fig. 2 Herbivore occupancy as measured by total dung deposited $\left(\mathrm{ml} \mathrm{m}^{-2} \mathrm{yr}^{-1}\right)$ for April-April periods, mean \% Calluna shoot utilisation recorded in April at the end of these periods, and mean heights of Calluna recorded each September during the study, for the four sites.

Fig. 3 Changes in mean \% cover for main species groups at the four sites. Key: red = ericoids, blue $=$ bryophytes, green $=$ graminoids-herbs, black $=$ unpalatable graminoids, ochre $=$ lichens.

Fig. 4a Change in total number of species number observed at recordings at the four sites. Key: black $=\mathrm{D} 2$, red $=\mathrm{L} 2$, blue $=\mathrm{L} 1$, green $=\mathrm{O} 2$.

Fig. $4 \mathrm{~b}$ Change in mean number of species hit point in recordings at the four sites. Key: black $=\mathrm{D} 2$, red $=\mathrm{L} 2$, blue $=\mathrm{L} 1$, green $=\mathrm{O} 2$. 
Table 1 Site information (soil data (means of eight plots) from measurements in autumn 1971; heather growth is the overall mean calculated from means measured in every year of the study and with a standard error based on year means; \% cover, with standard errors based on mean cover in the eight plots; heather height, with standard errors based on mean heights in the eight plots).

\begin{tabular}{lllll}
\hline & \multicolumn{1}{c}{ Site D2 } & Site L1 & Site L2 & Site O2 \\
\hline Location & $\begin{array}{l}\text { Ennochie, } \\
\text { Aberdeenshire } \\
\text { NO627914 }\end{array}$ & $\begin{array}{l}\text { Newbigging, } \\
\text { Aberdeenshire } \\
\text { NO147851 }\end{array}$ & $\begin{array}{l}\text { Clunie Lodge, } \\
\text { Aberdeenshire } \\
\text { NO140828 }\end{array}$ & $\begin{array}{l}\text { Cairnwell } \\
\text { Perthshire } \\
\text { NO140772 }\end{array}$ \\
Initial year observed & 1970 & 1969 & 1969 & 1969 \\
& & & & \\
Altitude (m) & 107 & 426 & 426 & 701 \\
Topography & flat & $8^{\circ} \mathrm{W}$ slope & $1^{\circ} \mathrm{N}$ slope & $5^{\circ}$ E slope \\
& & & & \\
Soil type & podsol & brown earth & peaty gley & brown earth \\
Initial pH & 4.6 & 5.1 & 3.8 & 5.3 \\
Extractable $\mathrm{K}^{\wedge}$ & 14 & 12 & 9 & 11 \\
Extractable $\mathrm{Ca}^{\wedge}$ & 14 & 21 & 16 & 103
\end{tabular}

Grazing regime unrestricted, unrestricted, unrestricted, unrestricted, and situation improved grassld no access to no access to no access to rarely available improved grassld improved grassld improved grassld

Main herbivore sheep sheep sheep

Subsidiary herbivores cattle, red deer, red deer, mountain hares Initial \% cover in year 1

$\begin{array}{lllll}\text { Calluna } & 86 \pm 2 & 65 \pm 4 & 60 \pm 6 & 29 \pm 6 \\ \text { Agrostis + Festuca } & 27 & 98 & 16 & 68\end{array}$

Annual mean growth of Calluna shoots (cm) $\quad 3.5 \pm 0.1 \quad 3.9 \pm 0.1 \quad 4.0 \pm 0.1 \quad 2.5 \pm 0.1$

Height Calluna $(\mathrm{cm})$

$\begin{array}{lrrrr}\text { Year 0 } & 7.4 \pm 0.4 & 14.1 \pm 1.0 & 11.1 \pm 0.5 & 9.6 \pm 0.6 \\ \text { Year 21 } & 16.2 \pm 1.3 & 16.7 \pm 0.9 & 19.0 \pm 1.3 & 15.0 \pm 0.6 \\ \text { Year 44 } & 20.3 \pm 0.9 & 21.2 \pm 0.9 & 21.7 \pm 2.0 & 14.9 \pm 1.0\end{array}$

$\wedge$ expressed as mg dry weight $100 \mathrm{ml}^{-1}$ 
Fig. 1 Location of the four study sites and two meteorological stations $(+, A=$ Aboyne, $B=$ Braemar) within inset from a map of Scotland.

7

8

9
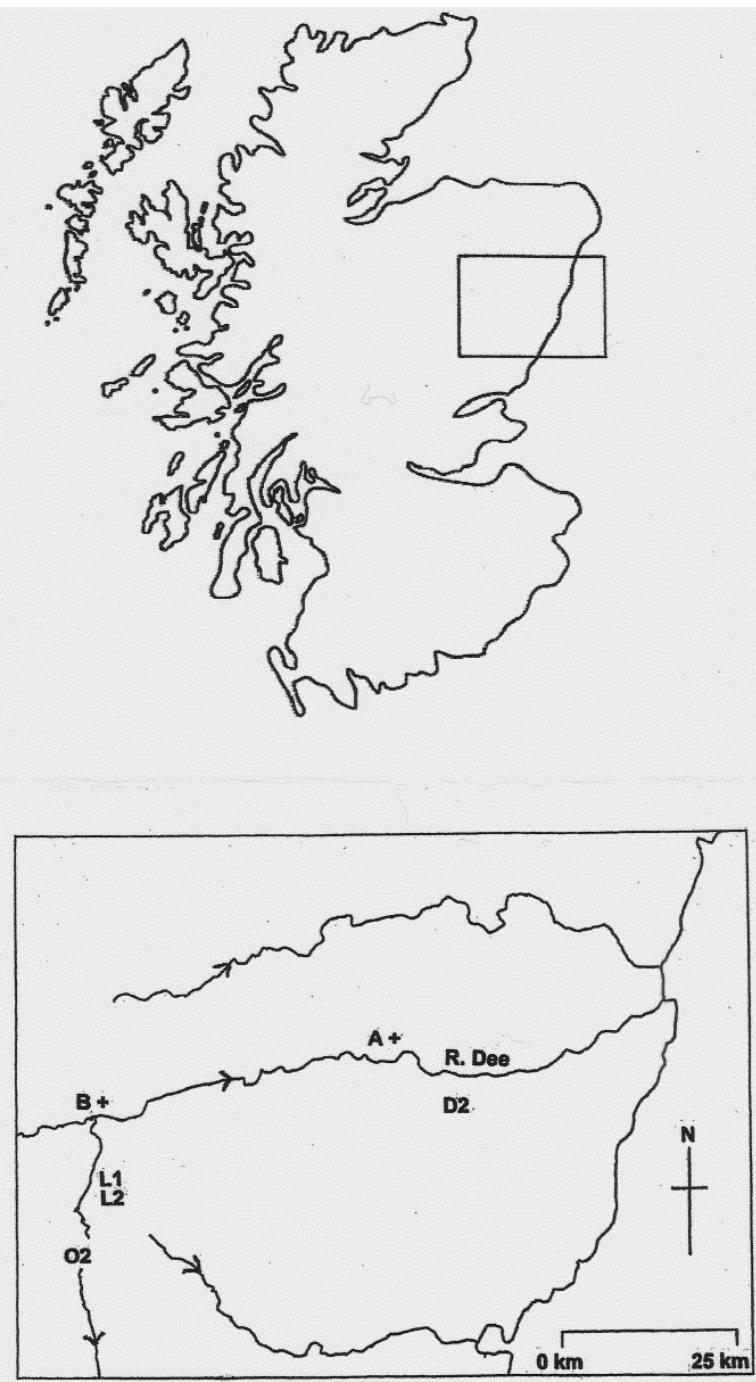
Table 2 Vegetation composition at the four sites, a) main species (i.e. species with overall mean cover $>\mathbf{2 0} \%$ ) and b) mean and total species number, based on all point-quadrat recordings made during the 43/44 years of study. Standard errors are given for the means of species number.

a) main species

Site D2

Calluna vulgaris

Pleurozium schreberi

Site L2

Calluna vulgaris

Deschampsia flexuosa

Hypnum cupressiforme

Pleurozium schreberi

b) species number
Site L1

Agrostis capillaris

Calluna vulgaris

Festuca ovina

Hylocomium splendens

\section{Site $\mathbf{O 2}$}

Agrostis capillaris

Calluna vulgaris

Deschampsia flexuosa

Festuca ovina

Hylocomium splendens

Dicots

Monocots

\section{$\begin{array}{rrrr}6.4 \pm 0.3 & 21.3 \pm 0.8 & 6.8 \pm 0.3 & 27.6 \pm 0.8\end{array}$}

$\begin{array}{llll}9.9 \pm 0.3 & 9.8 \pm 0.2 & 11.0 \pm 0.3 & 18.4 \pm 0.2\end{array}$

Bryophytes

$\begin{array}{llll}8.9 \pm 0.4 & 9.6 \pm 0.3 & 14.9 \pm 0.5 & 15.4 \pm 0.5\end{array}$

Monocots

$\begin{array}{llll}4.7 \pm 0.4 & 1.6 \pm 0.3 & 2.1 \pm 0.2 & 3.3 \pm 0.3\end{array}$

Total No. Species seen over $43 / 44$ years in all recordings over $43 / 44$ years at sites at sites

$\begin{array}{lllllllll}\text { All Species } \quad 30.1 \pm 1.2 & 42.3 \pm 1.1 & 34.8 \pm 1.6 & 64.6 \pm 1.3 & 54 & 67 & 55 & 107\end{array}$


Figure 2 Herbivore occupancy as measured by total dung volume deposited (ml $\mathrm{m}^{-2} \mathrm{yr}^{-1}$ ) for April-April periods, mean \% Calluna shoot utilisation recorded in April at the end of these periods, and mean heights of Calluna swards recorded each September during the study, for the four sites.

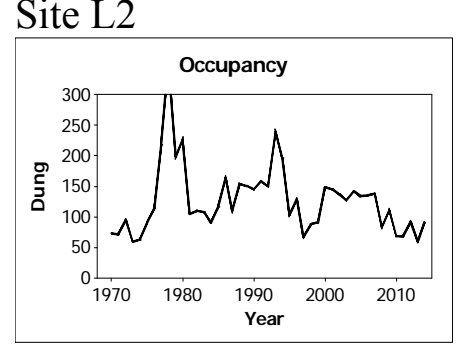

Site L1
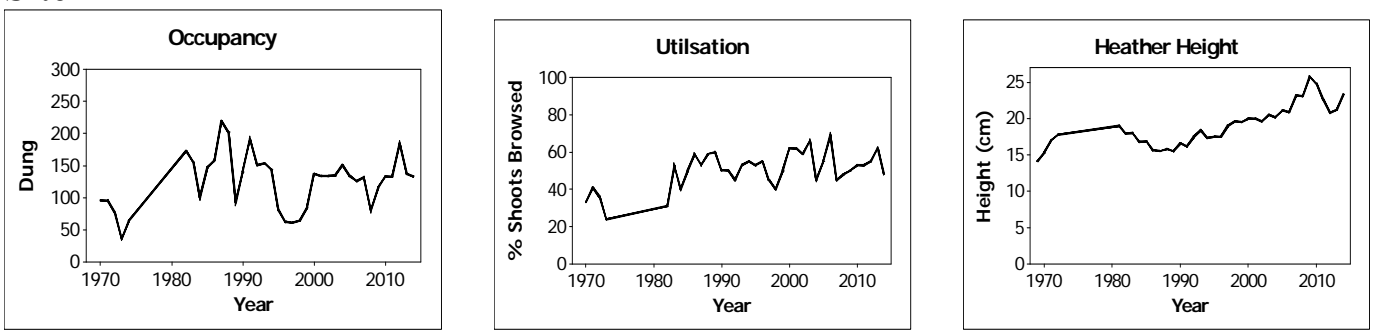

Site D2
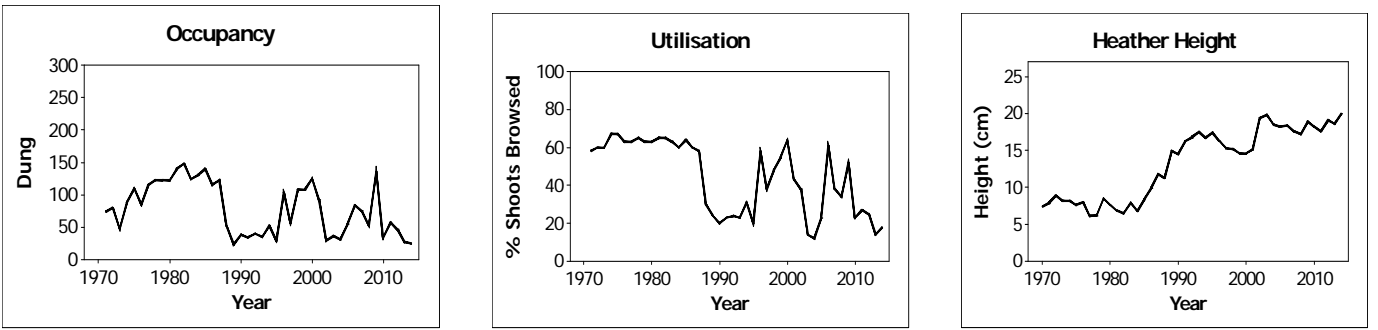

Site L2
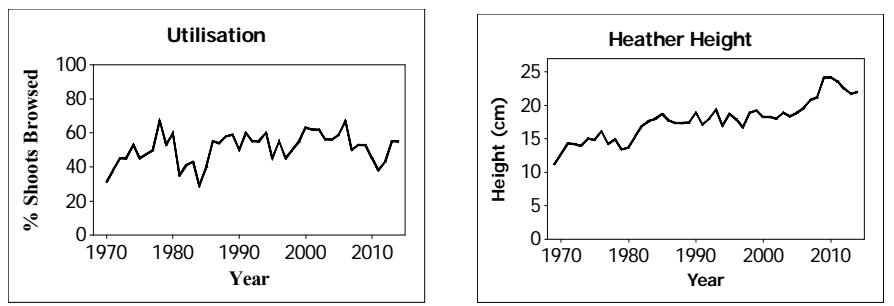

Site O2
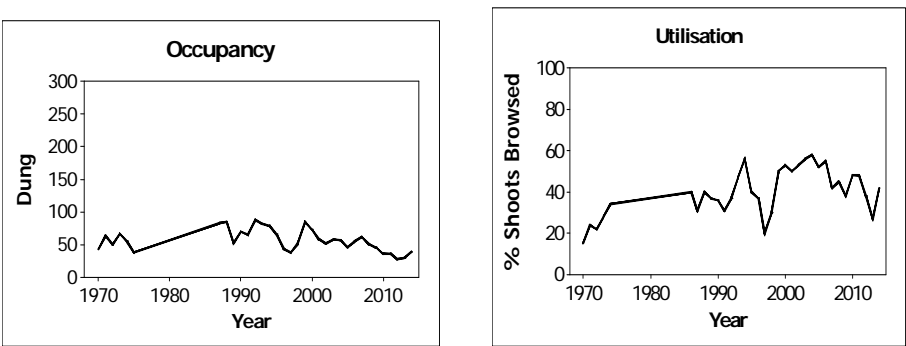
Figure 3 Changes in mean \% cover for main species groups at the four sites. 4 Key: red $=$ ericoids, blue $=$ bryophytes, green $=$ graminoids-herbs, black $=$ 5 unpalatable graminoids, ochre = lichens.

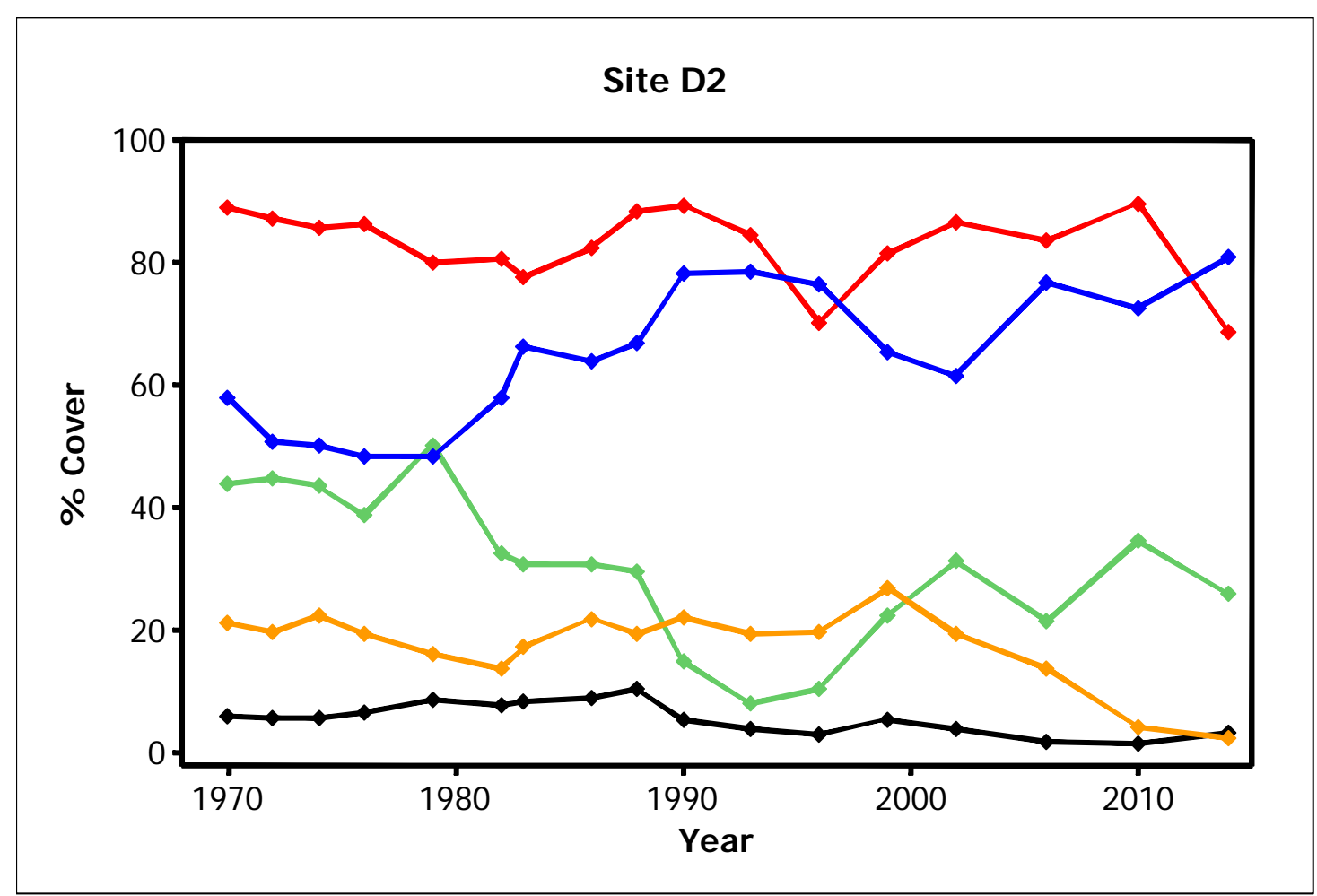

Site L1

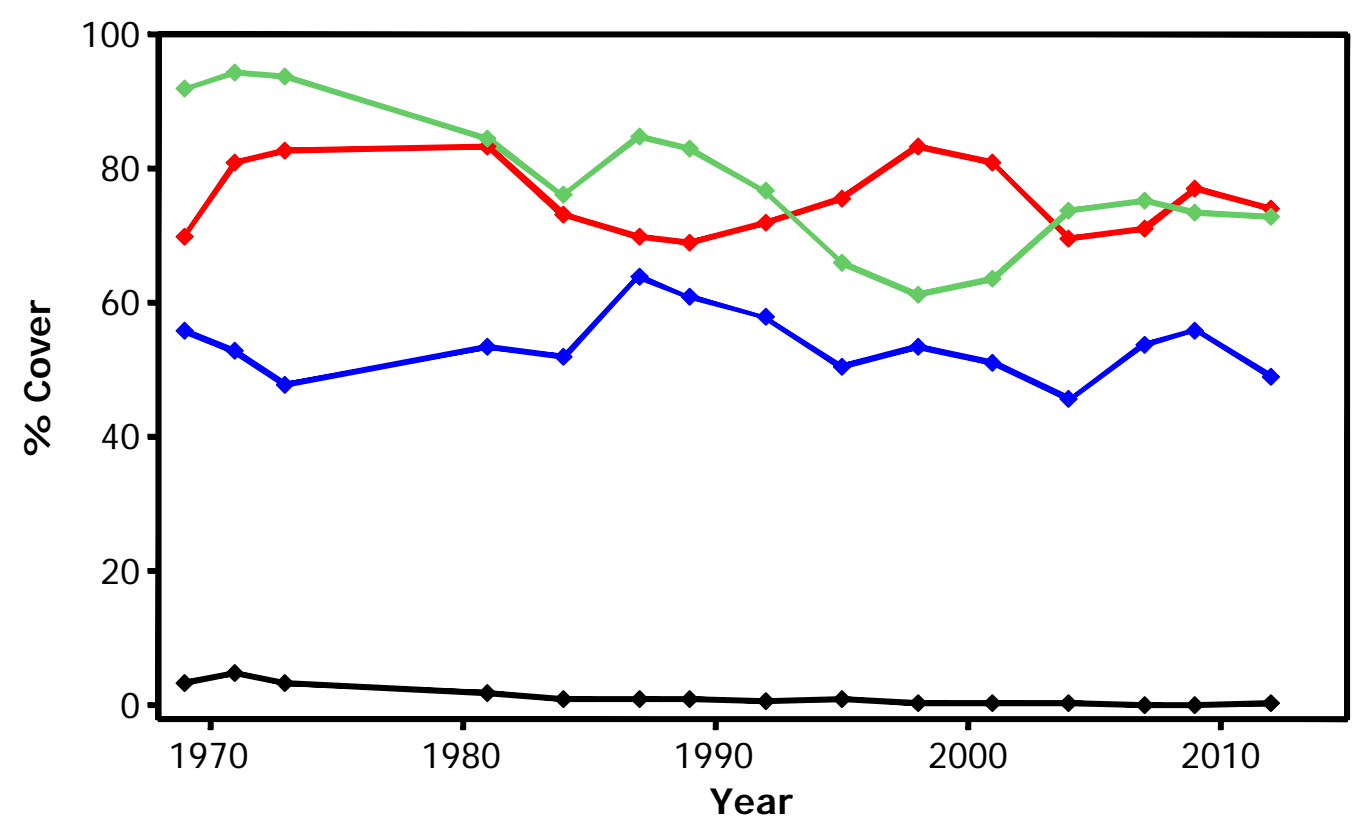


Site L2

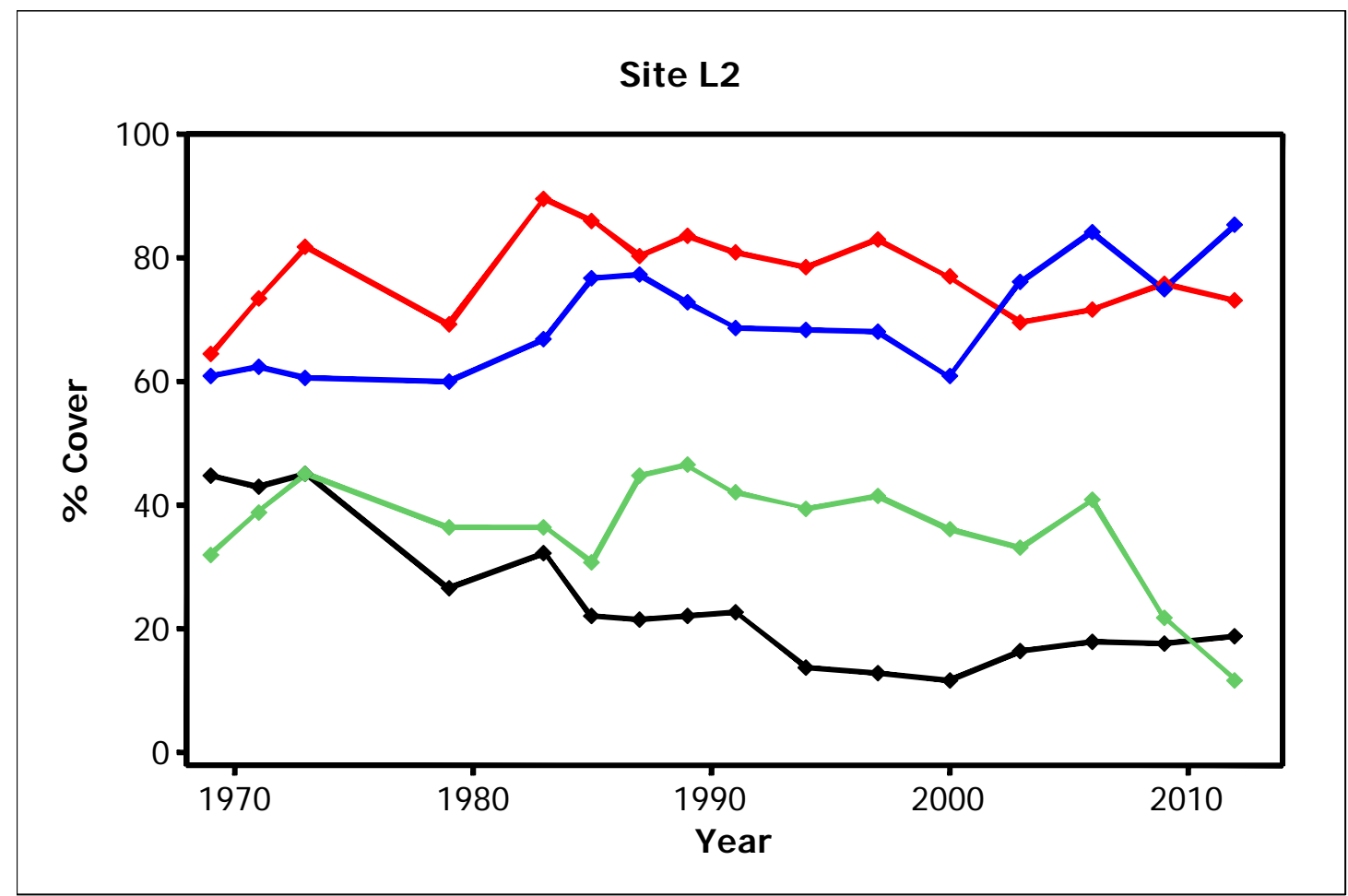

5
6
7
8

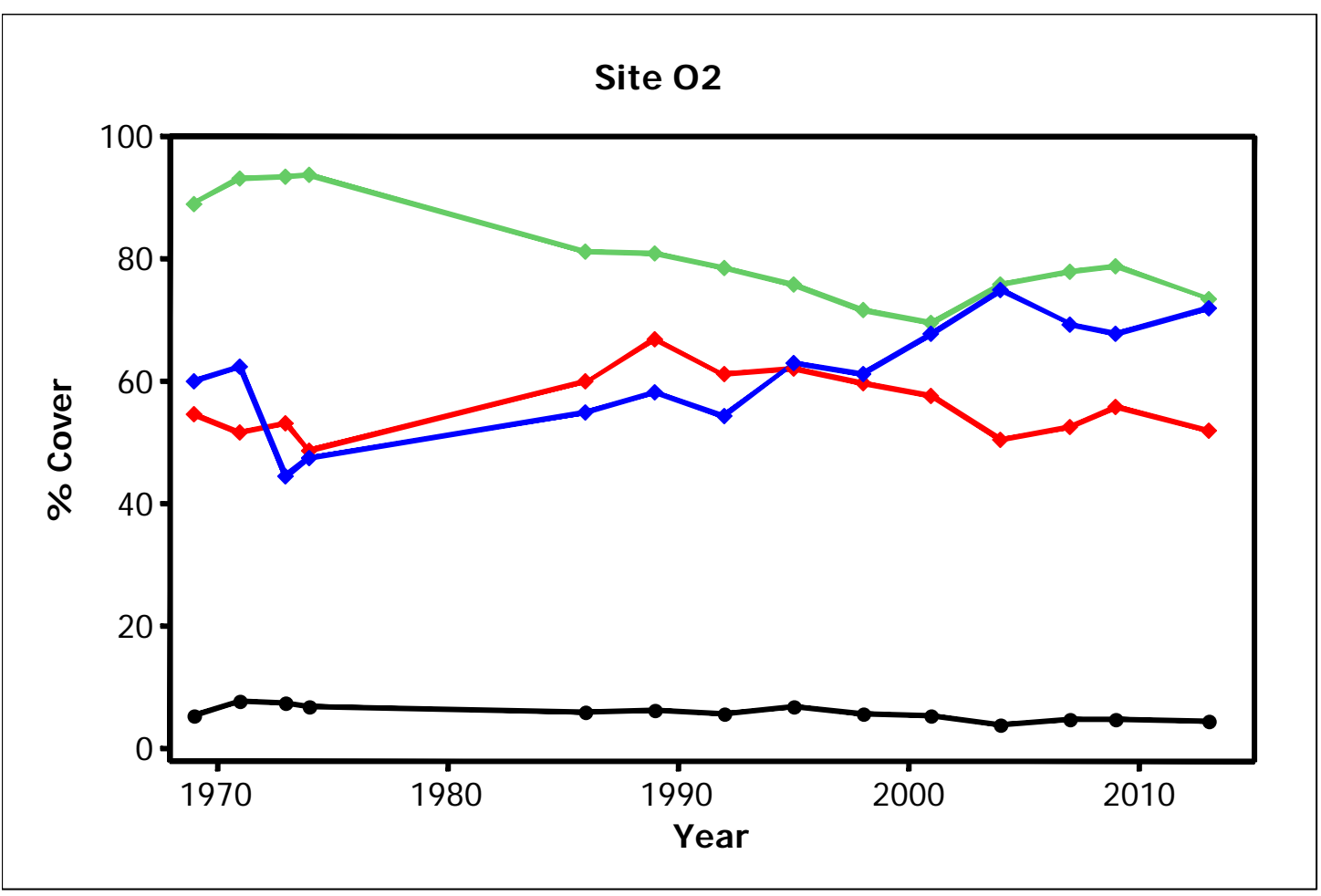

10

11

12 
Table 3 Change in cover of main species (those exceeding $10 \%$ cover in at least one recording), as shown by mean cover at the start (years 0 and 2), middle (years 20 and 22/23) and final (years 40 and 43/44) of observations. Stable species not having significant changes over time in linear regression are in bold; for other species regression significances and direction are shown: $* * * \boldsymbol{P}<0.001, * * \boldsymbol{P}<0.01$, * $P<0.05,+$ positive, - negative. For every species the far-right column gives $\%$ occurrence in all recordings of reversals to overall direction of change.

\begin{tabular}{ccccc}
\hline $\begin{array}{c}\text { \% Cover } \\
\text { Start }\end{array}$ & $\begin{array}{c}\% \text { Cover } \\
\text { Middle }\end{array}$ & $\begin{array}{c}\% \text { Cover } \\
\text { Final }\end{array}$ & $\begin{array}{c}\text { Change } \\
\text { Significance }\end{array}$ & $\begin{array}{c}\text { \% Direction } \\
\text { Reversals }\end{array}$ \\
& & &
\end{tabular}

\section{Site D2}

Calluna vulgaris

Hypnum cupressiforme

Leucobryum glaucum

Pleurozium schreberi

Cladonia impexa

Deschampsia flexuosa

Hylocomium splendens

Carex panicea

Erica cinerea

Festuca ovina

Nardus stricta

Site L1

Calluna vulgaris

Galium saxatile

Rhytidiadelphus squarrosus

Vaccinium myrtillus

Hylocomium splendens

Festuca ovina

Hypnum cupressiforme

Potentilla erecta

Anthoxanthum odoratum

Erica cinerea

Agrostis capillaris

Carex pilulifera

Pleurozium schreberi

Site L2

Calluna vulgaris

Deschampsia flexuosa

Juncus squarrosus

Hylocomium splendens

Pleurozium schreberi

Hypnum cupressiforme

Nardus stricta

Festuca ovina

Site $\mathbf{O 2}$

Agrostis capillaris

Empetrum nigrum

Festuca ovina

Galium saxatile
84.4

9.8

11.8

34.0

14.4

1.1

0.1

10.9

12.6

22.0

5.3

71.4

15.9

9.5

5.6

16.5

54.3

15.9

16.6

13.6

8.4

52.9

18.9

16.1

65.5

18.1

11.0

1.2

9.8

36.9

33.1

8.6

30.4

11.8

27.6

10.9
85.9

\section{1}

10.4

65.1

18.8

6.2

3.4

0.7

4.4

2.1

4.4

66.5

16.8

13.6

7.4

18.8

41.8

9.3

8.6

4.4

6.6

39.6

7.4

22.3

81.6

31.0

5.7

\section{3}

27.2

33.3

15.7

8.4

19.3

19.3

25.2

7.2
78.8

14.5

8.8

35.1

3.3

16.3

26.3

0.7

0.2

10.0

2.2

73.4

16.2

8.5

\section{7}

32.3

34.3

3.5

7.9

3.6

3.3

39.4

7.8

6.4

73.7

11.0

8.7

37.0

24.0

20.9

6.8

2.7

31.0

12.7

26.0

10.0
44

38

50

50

44

38

19

31

31

44

50

43

43

50

36

43

36

21

36

36

43

29

29

36

53

47

40

33

40

33

53

27

38

69

46

46 


$\begin{array}{lrrrrrr}\text { Rhytidiadelphus squarrosus } & \mathbf{6 . 6} & \mathbf{6 . 9} & \mathbf{5 . 2} & & & \mathbf{4 6} \\ \text { Hylocomium splendens } & 33.6 & 35.3 & 56.1 & + & * * * & 31 \\ \text { Calluna vulgaris } & 29.7 & 40.6 & 39.3 & + & * * & 31 \\ \text { Deschampsia flexuosa } & 31.2 & 20.9 & 11.4 & - & * * * & 38 \\ \text { Festuca rubra } & 16.5 & 3.6 & 1.5 & - & * * * & 46 \\ \text { Alchemilla alpina } & 17.4 & 20.4 & 8.3 & - & * * & 38 \\ \text { Vaccinium myrtillus } & 19.2 & 19.9 & 9.0 & - & * * & 38 \\ \text { Anthoxanthum odoratum } & 9.1 & 4.4 & 4.0 & - & * & 46 \\ \text { Pleurozium schreberi } & 19.3 & 13.5 & 9.4 & - & * & 38 \\ \text { Thymus polytrichus } & 12.8 & 10.1 & 5.9 & - & * & 23\end{array}$

11

12

13

14

15

16

17

18

19

20

21

22

23

24

25

26

27

28

29

30

31

32

33

34

35

36

37

38

39

40

41

42

43

44

45

46

47

48

49

50

51 
Table 4 Average and final \% cover of new species and timing of their entry in years from the start of observations. New species were defined as ones not occurring at the first and second recordings, and to qualify for the table they needed 3 or more occurrences at a site and presence in both the last 2 recordings there. No species qualified at sites L1 and L2. Standard errors are given.

\begin{tabular}{lccc}
\hline & $\begin{array}{c}\% \\
\text { Average } \\
\text { Cover }\end{array}$ & $\begin{array}{c}\text { \%inal } \\
\text { Cover }\end{array}$ & $\begin{array}{c}\text { Year } \\
\text { of Entry }\end{array}$ \\
\hline $\begin{array}{l}\text { Site D2 qualifying species } \\
\text { Rhytidiadelphus squarrosus }\end{array}$ & 0.4 & $1.2 \pm 0.5$ & 16 \\
Site O2 qualifying species & & & \\
$\begin{array}{l}\text { Helianthemum nummularium } \\
\text { Lathyrus linifolius }\end{array}$ & 0.2 & $0.4 \pm 0.3$ & 17 \\
$\begin{array}{l}\text { Lophocolea bidentata } \\
\text { Pseudoscleropodium purum }\end{array}$ & 0.1 & $0.1 \pm 0.1$ & 26 \\
& 0.3 & $0.3 \pm 0.2$ & 20 \\
& 0.2 & $0.3 \pm 0.3$ & 26 \\
\hline
\end{tabular}


Table 5 Initial and average \% cover of lost species and timing of their last occurrence in years from the start of observations. Species were considered lost if absent in the final three recordings but having at least 4 earlier occurrences at a site. Initial \% cover was the mean of cover in the first two recordings, and average cover was calculated from cover in all recordings from the first up to the last in which the species was recorded. Standard errors are given.

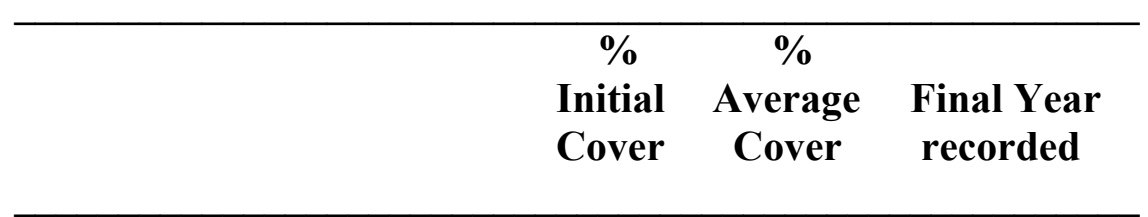

\section{Site D2}

Trichophorum germanicum

$0.1 \pm 0.1$

0.1

13

Aulacomnium palustre

$0.1 \pm 0.1$

0.2

$0.1 \pm 0.1$

0.2

6

Calypogeia fissa

$0.8 \pm 0.3$

0.4

6

Lophocolea bidentata

$0.1 \pm 0.1$

32

Pohlia nutans

$0.4 \pm 0.2$

0.1

16

Polytrichum commune

$3.3 \pm 0.9$

0.3

26

Cladonia uncialis

$0.7 \pm 0.3$

1.6

26

Cornicularia aculeata

$3.6 \pm 0.5$

0.4

13

Parmelia physodes

$0.3 \pm 0.1$

0.1

18

Blechnum spicant

$0.3 \pm 0.1$

0.1

32

Plagiomnium undulatum

$0.1 \pm 0.1$

0.1

32

Plantago lanceolata

$0.1 \pm 0.1$

0.1

Thuidium tamariscinum

$0.1 \pm 0.1$

0.1

Cladonia impexa

$0.1 \pm 0.1$

0.1

35

Site L2

Carex panicea

$0.6 \pm 0.2$

31

Erica tetralix

$0.1 \pm 0.1$

0.3

22

Genista anglica

$0.1 \pm 0.1$

0.2

31

Campylopus flexuosus

$1.3 \pm 0.4$

0.1

$0.3 \pm 0.1$

0.7

14

Pohlia nutans

$0.3 \pm 0.2$
$0.0 \pm 0.0$
$0.0 \pm 0.0$

0.3
0.1
0.1
5

Calliergonella cuspidata

Plagiomnium rostratum

Warnstorfianum fluitans

$0.0 \pm 0.0$

0.1

29

35 
2 Figure 4a Change in total number of species observed at recordings at the four 3 sites. Key: black $=$ D2, red $=\mathbf{L 2}$, blue $=\mathbf{L 1}$, green $=\mathbf{O 2}$.

5

6

$$
7
$$

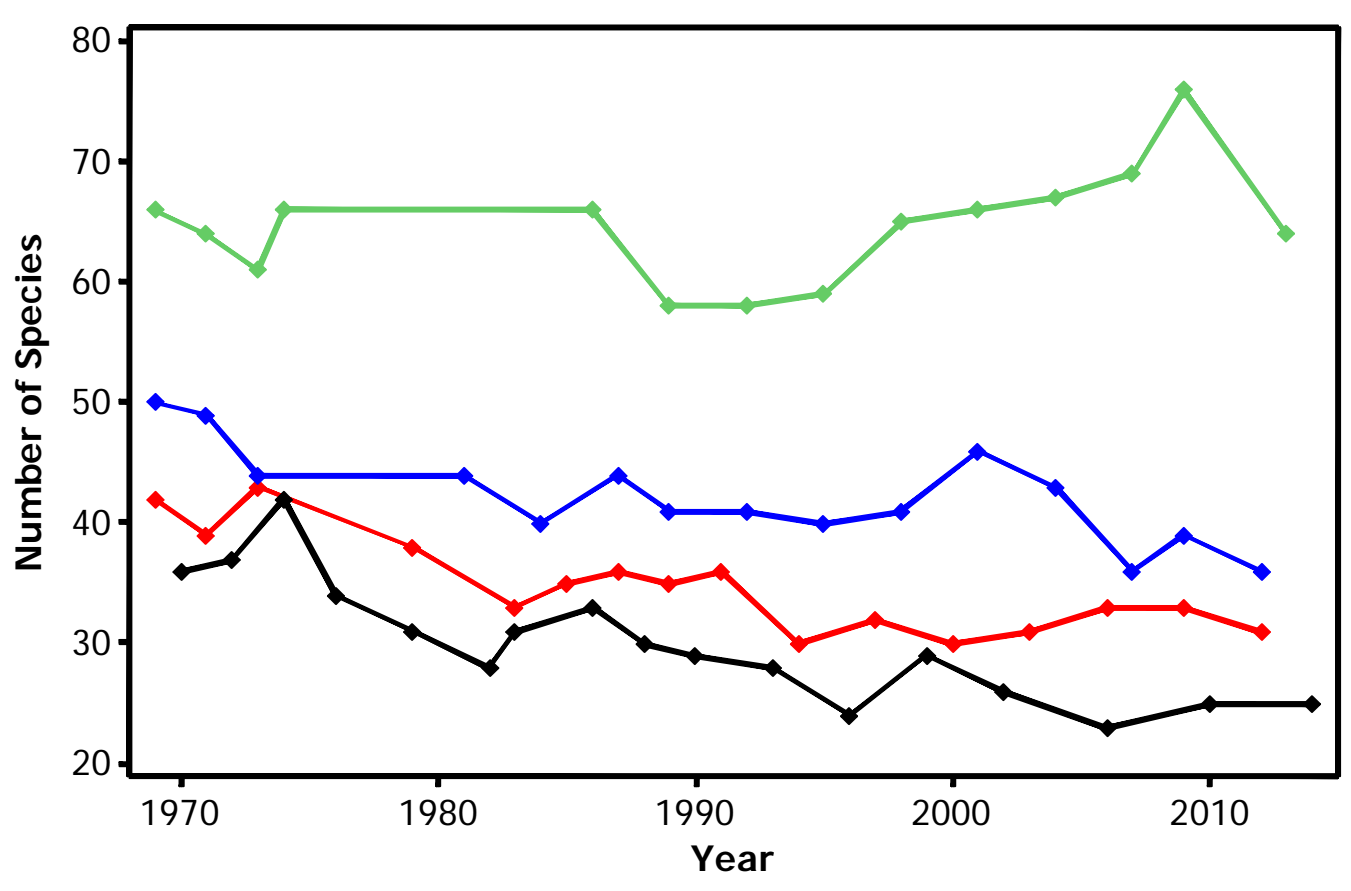


Figure 4b Change in mean number of species hit per point in recordings at the four sites. Key: black $=D 2$, red $=L 2$, blue $=L 1$, green $=02$.

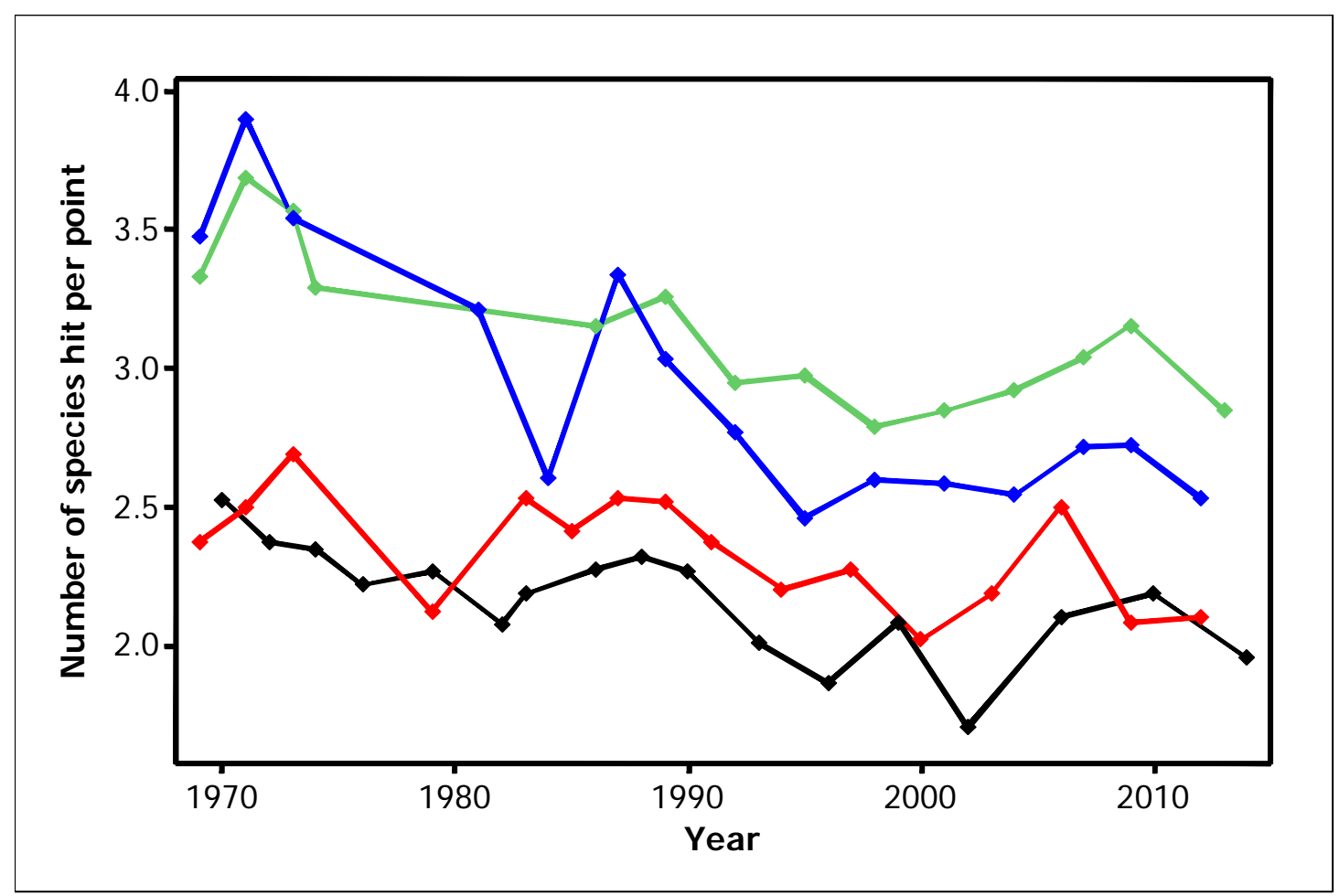


Table 6 Affinities to NVC types in British Plant Communities of the moorland communities at the four sites, for a) composition at the start of observations, and $b$ ) at the final recordings in years $43 / 44$ of the study. The three most-closely related NVC types are given together with goodness-offit $X^{2}$ values obtained in TABLEFIT analyses; for a) the analyses used only species with cover $>1 \%$, but for $b$ ) second analyses used all species present.

\begin{tabular}{|c|c|c|c|c|c|c|}
\hline \multirow[t]{3}{*}{ Site } & \multirow{2}{*}{\multicolumn{2}{|c|}{$\begin{array}{c}\text { a } \\
\text { Composition } \\
\text { in year } 1 \\
\text { Spp }<1 \% \text { excluded }\end{array}$}} & \multicolumn{4}{|c|}{$\begin{array}{c}\mathrm{b} \\
\text { Final Composition } \\
\text { in year } 43 / 44\end{array}$} \\
\hline & & & \multicolumn{2}{|c|}{ Spp $<1 \%$ excluded } & \multicolumn{2}{|c|}{ All spp included } \\
\hline & NVC type & $\mathrm{X}^{2}$ & NVC type & $X^{2}$ & NVC type & $X^{2}$ \\
\hline \multirow[t]{3}{*}{ D2 } & $\mathrm{H} 10$ & 79 & $\mathrm{H} 10$ & 64 & $\mathrm{H} 10$ & 60 \\
\hline & $\mathrm{H} 10 \mathrm{a}$ & 66 & $\mathrm{H} 21 \mathrm{a}$ & 60 & $\mathrm{H} 18 \mathrm{a}$ & 60 \\
\hline & $\mathrm{H} 10 \mathrm{c}$ & 65 & $\mathrm{H} 18 \mathrm{a}$ & 58 & $\mathrm{H} 21$ & 60 \\
\hline \multirow[t]{3}{*}{ L1 } & CG11a & 80 & $\mathrm{U} 4 \mathrm{a}$ & 81 & $\mathrm{U} 4 \mathrm{a}$ & 71 \\
\hline & $\mathrm{U} 4 \mathrm{a}$ & 77 & $\mathrm{U} 4 \mathrm{~d}$ & 75 & CG10a & 70 \\
\hline & CG10a & 72 & U5d & 72 & CG11a & 69 \\
\hline \multirow[t]{3}{*}{ L2 } & U5 & 74 & $\mathrm{H} 10$ & 64 & $\mathrm{H} 21$ & 62 \\
\hline & U5d & 69 & $\mathrm{H} 18 \mathrm{a}$ & 59 & $\mathrm{H} 18 \mathrm{a}$ & 61 \\
\hline & U5e & 68 & $\mathrm{H} 21$ & 59 & $\mathrm{H} 21 \mathrm{a}$ & 59 \\
\hline \multirow[t]{3}{*}{$\mathrm{O} 2$} & CG11a & 82 & CG11a & 78 & CG11a & 64 \\
\hline & $\mathrm{H} 18 \mathrm{~b}$ & 78 & $\mathrm{H} 18 \mathrm{~b}$ & 71 & $\mathrm{H} 18 \mathrm{~b}$ & 53 \\
\hline & CG11 & 77 & CG10b & 67 & CG10b & 53 \\
\hline
\end{tabular}

